\title{
Audit Certificate
}

National Cancer Institute

\section{Source}

National Cancer Institute. Audit Certificate. NCI Thesaurus. Code C115469.

Official records that an examination of accounts and records was performed and completed. 